\title{
Pengembangan LKPD Matematika HOTS (Higher of Order Thinking Skills) Berorientasi Kearifan Lokal Daerah untuk Sekolah Dasar
}

\author{
${ }^{1}$ Nawang Sulistyani, ${ }^{2}$ Tyas Deviana \\ Pendidikan Guru Sekolah Dasar, Fakultas Keguruan dan Ilmu Pendidikan, \\ Universitas Muhammadiyah Malang \\ Email: nawang_sulistyani@umm.ac.id, tyasdefiana@umm.ac.id*
}

\begin{abstract}
The improvement 2013 curriculum has implications for the exit of mathematics from thematic learning. However, this separation don't ignore 4C skills which include critical, creative, collaborative, and communication. One of these skills can be achieved through HOTS (Higher of Order Thingking Skills) learning. One of the HOTS learning achievements, which is proven through student learning activities that reflect learning with high level thinking skills. One of the teaching materials which contains various learning activities is the Student Activity Sheet (LKPD). The purpose of this research is to produce a HOTS Mathematics Student Worksheet which is oriented towards local of Malang city for elementary schools which is valid, interesting, practical and effective. The research method used was the Dick \& Carey research and development model. The subjects of this study were all 5th students of SD Muhammadiyah 5 Malang. The type of data used is qualitative data obtained from the validation responses of experts, teachers and students in the form of suggestions for improvement, while quantitative data is obtained from the results of learning activities of students and the calculation of the response questionnaire validation from experts, teachers and students. Based on the results of field trials, it was found that the HOTS Mathematics Worksheet was oriented towards local wisdom of Malang City which was developed to be very valid, interesting, practical and effective in facilitating students in a more meaningful mathematics learning which is integrated with the environment around the students.
\end{abstract}

Keywords: HOTS, Local Wisdom, LKPD Mathemamatics, Elementary School

\begin{abstract}
Abstrak . Kurikulum 2013 yang telah disempurnakan, berimplikasi pada keluarnya mata pelajaran matematika dari pembelajaran tematik. Namun demikian, pemisahan tersebut tidak mengabaikan kecakapan 4C yang meliputi critical, creative, colaboratif, dan communication. Kecakapan tersebut dapat dicapai salah satunya melalui pembelajaran HOTS (Higher of Order Thingking Skills). Salah satu ketercapaian pembelajaran HOTS, yaitu dibuktikan melalui kegiatan belajar Peserta Didik yang mencerminkan pembelajaran dengan keterampilan berfikir tingkat tinggi. Salah satu bahan ajar yang di dalamnya memuat berbagai kegiatan belajar yaitu Lembar Kegiatan Peserta Didik (LKPD). Tujuan penelitian ini yaitu menghasilkan LKPD Matematika HOTS berorientasi pada kearifan lokal Kota Malang untuk Sekolah Dasar yang valid, menarik, praktis dan efektif. Metode penelitian yang digunakan adalah model penelitian dan pengembangan Dick \& Carey. Subjek penelitian ini adalah seluruh peserta didik kelas V SD Muhammadiyah 5 Kota Malang. Jenis data yang digunakan yaitu data kualitatif yang diperoleh dari tanggapan validasi ahli, guru dan peserta didik yang berupa saran perbaikan, sedangkan data kuantitatif diperoleh dari hasil hasil aktivitas belajar peserta didik serta perhitungan angket respon validasi ahli, guru dan peserta didik. Berdasarkan hasil uji coba di lapangan diperoleh hasil bahwa LKPD Matematika HOTS berorientasi pada kearifan lokal kota Malang yang dikembangkan sangat valid, menarik, praktis dan efektif dalam memfasilitasi peserta didik pada pembelajaran matematika yang lebih bermakna yang diintegrasikan dengan lingkungan sekitar peserta didik.
\end{abstract}

Kata Kunci: HOTS, Kearifan Lokal, LKPD, Matematika, Sekolah Dasar

\section{PENDAHULUAN}

Pandemi Covid-19 telah menjangkau seluruh wilayah negara Indonesia. Menanggapi pandemi yang masih berlangsung hingga saat ini, Pemerintah terus menetapkan kebijakan pembelajaran daring (dalam jaringan) di semua jenjang pendidikan. Meskipun demikian, pembelajaran di sekolah dituntut untuk dapat melatih peserta didik untuk berpikir kritis dan kreatif. Hal ini berimplikasi pada implementasi pembelajaran matematika di jenjang Sekolah Dasar (SD) karena adanya keterkaitan satu konsep dengan konsep yang lainnya. Sehingga peserta didik harus mampu memahami konsep dasar untuk bisa melanjutkan materi jenjang kelas berikutnya.

Pembelajaran matematika di SD tentunya tidak mengabaikan kecakapan $4 \mathrm{C}$ yang meliputi critical, creative, colaboratif, dan communication. Kecakapan tersebut dapat dicapai salah satunya melalui pembelajaran HOTS (Higher of Order Thingking Skills) yang ditandai dengan adanya kegiatan pembelajaran menurut taksonomi Bloom pada aspek kognitif 
yang dimulai pada C4 sampai C6. Melalui kegiatan pembelajaran yang HOTS maka diharapkan tercapainya kecakapan $4 \mathrm{C}$.

Kemampuan berpikir tingkat tinggi (HOTS) merupakan salah satu kompetensi penting dalam dunia modern, sehingga wajib dimiliki oleh setiap peserta didik (Florea \& Hurjui, 2015). Salah satu ketercapaian pembelajaran HOTS, yaitu dibuktikan melalui kegiatan belajar Peserta Didik yang mencerminkan pembelajaran dengan keterampilan berfikir tingkat tinggi. Salah satu bahan ajar yang di dalamnya memuat berbagai kegiatan belajar yaitu Lembar Kegiatan Peserta Didik (LKPD).

LKPD HOTS diperlukan untuk melatih berpikir kritis dan kreatif dalam menyelesaikan soal-soal pada kategori menganalisis, mengevaluasi, dan mencipta (Noprinda \& Soleh, 2019). Hal ini didukung oleh Fitria, Wijaya, \& Danial (2020) LKPD HOTS dapat meningkatkan aktivitas dan hasil belajar peserta didik dengan kriteria level kemampuan berpikir tingkat tinggi. Selain itu, LKPD dapat mempermudah dalam memahami materi maupun mempraktikkan percobaan baik di dalam dan luar kelas serta di rumah (Muzayyanah, Wijayanti, \& Ardiyanto, 2020). Sehingga LKPD dapat digunakan untuk melengkapi bahan ajar matematika dalam proses pembelajaran di sekolah dasar (Septian, Irianto, \& Andriani, 2019).

Hasil observasi lapang diperoleh bahwa guru SD hanya menggunakan buku siswa dan LKS dari penerbit sebagai bahan ajar matematika. Hasil analisis terhadap bahan ajar yang digunakan belum dapat mengukur keterampilan berpikir tingkat tinggi peserta didik. Hal ini sejalan dengan temuan Sulistyani \& Deviana, (2019) secara umum materi yang disajikan pada bahan ajar kelas V SD lebih pada penemuan konsep yang dipelajari peserta didik, belum sampai pada penerapan konsep Hal ini ditegaskan pula oleh Retnawati, Djidu, Kartianom, Apino, \& Anazifa (2018) bahwa pengetahuan guru tentang HOTS, kemampuan meningkatkan HOTS peserta didik, menyelesaikan soal berbasis HOTS, dan mengukur HOTS peserta didik masih rendah.

Hal yang tidak kalah penting dalam pembelajaran, selain dapat mengukur keterampilan berpikir tingkat tinggi yaitu peserta didik juga dapat belajar bermakna melalui pengenalan kearifan lokal daerah sekitar. Sehingga apa yang dipelajari dapat diimplementasikan dalam kehidupan sehari-hari. Pembelajaran yang diintegrasikan dengan kearifan lokal dapat mengembangkan karakter dan sumber daya manusia yang memiliki keterampilan kerja yang tinggi, budaya kerja dan budaya belajar yang kuat, serta budaya melayani masyarakat secara ikhlas dan wajar (Nasution, 2016).

Hasil wawancara dengan guru kelas 5 SD juga menunjukkan bahwa bahan ajar yang tersedia belum mengakomodasi kearifan lokal daerah sekitar. Contoh-contoh soal yang terdapat pada bahan ajar masih bersifat pemecahan masalah secara umum. Konsep materi yang disajikan masih perlu diintegrasikan dengan kearifan lokal daerah. Hal ini dikarenakan pengenalan suasana pendidikan belajar yang bermakna bagi peserta didik tidak terpisahkan dari kearifan lokal dan tradisi sosial (Kertih, 2020).

Penelitian yang telah dilakukan Widodo (2017) memperoleh hasil bahwa LKPD berbasis penedekatan saintifik dapat meningkatkan keterampilan penyelesaian masalah lingkungan sekitar peserta didik di Sekolah Dasar. Penelitian serupa dilakukan oleh Rahayu (2018) menyatakan bahwa LKPD berbasis pemecahan masalah dapat meningkatkan hasil belajar peserta didik pada materi bangun datar. Dalam pembelajaran matematika, LKPD yang diintegrasikan dengan kehidupan sehari-hari dapat mamfasilitasi kreativitas peserta didik untuk menemukan konsep dan mengembangkan berbagai ketrampilan dalam memecahkan susatu masalah (Umbaryati, 2018).

Berdasarkan uraian diatas, tujuan penelitian ini yaitu mengembangkan LKPD Matematika HOTS (Higher of Order Thinking Skills) berorientasi pada kearifan lokal kota Malang untuk kelas V Sekolah Dasar yang valid, menarik, praktis dan efekif.

\section{METODE}

Penelitian ini merupakan penelitian dan pengembangan (Research and Development) LKPD Matematika HOTS berorientasi kearifan 
lokal kota Malang untuk siswa kelas V SD dengan menggunakan model pengembangan Dick \& Carey. Peneliti melakukan sedikit modifikasi pada langkah-langkah pengembangan yang dilaksanakan. Modifikasi ini dilakukan untuk menyesuaikan dengan keadaan lapangan dan keterbatasan peneliti. Adapun prosedur penelitian dan pengembangan dapat dilihat pada gambar 1 berikut.

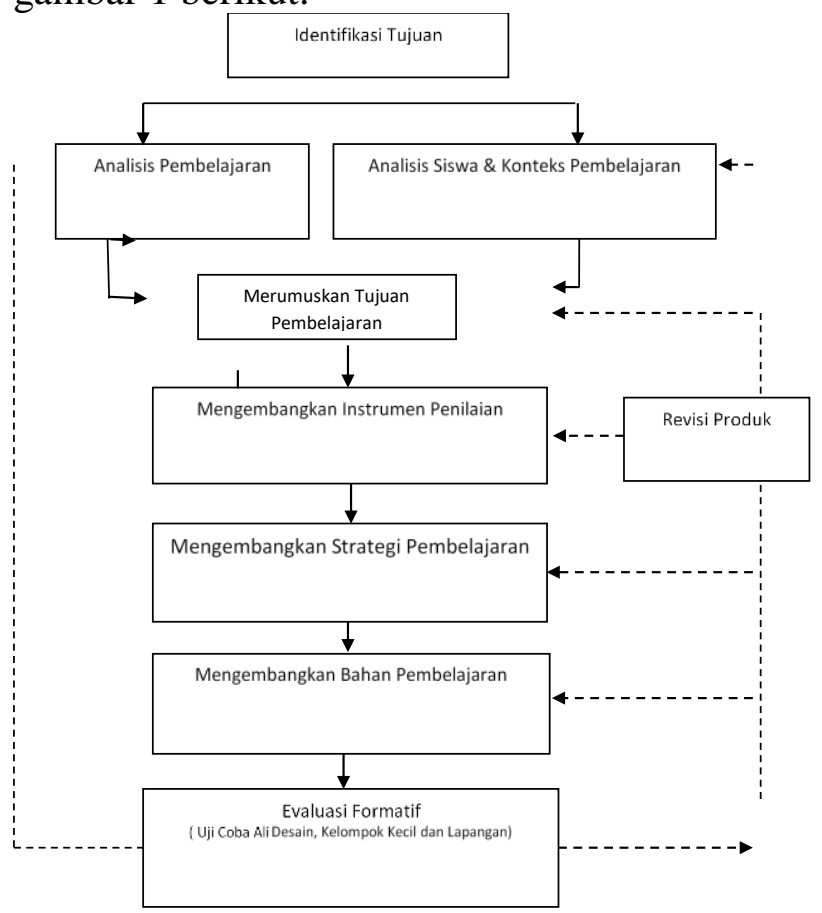

Gambar 1. Modifikasi Model Rancangan Pembelajaran Dick \& Carey

Uji coba produk dilakukan untuk mengetahui tingkat kevalidan, kemenarikan, kepraktisan, dan keefektifan produk serta digunakan sebagai dasar untuk melakukan revisi (perbaikan). Pada pelaksanaan uji coba produk terdapat lima langkah yang dilakukan yaitu: (1) desain uji coba yang terdiri dari tiga tahapan, yaitu uji coba prototipe, uji coba kelompok kecil, dan uji conba lapangan; (2) subjek coba yang terdiri dari ahli materi, siswa dan Guru kelas 5 SD Muhammadiyah 5 Kota Malang; (3) Jenis data yang berbrntuk data kualitatif dan kuantitatif; (4) instrumen pengumpulan data yang meliputi lembar validasi, angket, tes dan lembar observasi, dan (5) teknik analisis data yang terdiri analisis data tingkat kevalidan, kemenarikan, kepraktisan dan keefektifan produk.

\section{HASIL DAN PEMBAHASAN}

Hasil penelitian dan pengembangan yang telah dilakukan tentang pengembangan LKPD Matematika HOTS berorientasi kearifan lokal kota Malang untuk kelas V sekolah dasar dipaparkan sebagai berikut;

\section{a. Identifikasi Tujuan}

Identifikasi tujuan dilakukan peneliti melalui 4 kegiatan, Adapun penjelasan secara rinci masing-masing kegiatan yang telah dilakukan peneliti sebagai berikut.

\section{1) Studi pustaka}

Studi pustaka bertujuan untuk menemukan landasan teori yang berkaitan dengan LKPD HOTS berorientasi kearifan lokal kota Malang yang akan dikembangkan. Peneliti mengkaji standar isi pada kurikulum 2013. Hal ini dilakukan untuk menganalisis keterpaduan materi pembelajaran matematika di kelas V SD. Berdasarkan hasil analisis terhadap kurikulum, langkah selanjutnya yaitu memetakan kompetensi dasar yang sesuai dengan muatan materi matematika pada kelas V SD. Adapun pemetaan kompetensi dasar dipilih dua kompetensi dasar yang disajikan pada tabel 1 berikut;

Tabel 1. Pemetaan Kompetensi Dasar Matematika di Kelas V SD

\begin{tabular}{lll}
\hline No & \multicolumn{2}{c}{ Kompetensi Dasar } \\
\cline { 2 - 3 } & Pengetahuan & Keterampilan \\
\hline 1 & Menjelaskan, dan & Menyelesaikan \\
& menentukan volume & masalah yang \\
& bangun ruang & berkaitan dengan \\
& dengan & volume bangun ruang \\
& menggunakan satuan & dengan menggunakan \\
& volume (seperti & satuan volume \\
& kubus satuan) serta & (seperti kubus satuan) \\
& hubungan pangkat & melibatkan pangkat \\
& tiga dengan akar & tiga dan akar pangkat \\
& pangkat tiga & tiga \\
\hline 2 & Menjelaskan dan & Membuat jaring- \\
& menemukan jaring- & jaring bangun ruang \\
& jaring bangun ruang & sederhana (kubus dan \\
& sederhana (kubus & balok) \\
& dan balok) & \\
\hline
\end{tabular}

2) Studi pendahuluan/lapangan

Studi pendahuluan yang dilakukan oleh peneliti adalah observasi pada tiga sekolah di Kota Malang, yaitu: SD Muhammadiyah 8 Dau, SD Muhammadiyah 4 Malang dan SD Muhammadiyah 5 Malang serta wawancara 
kepada guru kelas $\mathrm{V}$ pada masing-masing sekolah tersebut. Beberapa aspek yang diamati peneliti yaitu: (1) kegiatan pembelajaran daring yang dilaksanakan, dan (2) perangkat yang digunakan guru dalam mengajar. Temuan dalam observasi, juga diperkuat dengan hasil wawancara yang telah dilakukan. Hasil temuan observasi dan wawancara digunakan peneliti untuk mengidentifikasi masalah yang dialami guru dalam pelaksanaan pembelajaran daring pada mata pelajaran matematika di kelas V SD. Berdasarkan studi lapangan di lokasi penelitian maupun di beberapa SD di Kota Malang diperoleh kesimpulan bahwa guru membutuhkan bahan ajar matematika yang dapat mengukur ketrampilan berpikir tingkat tinggi dan mengintegrasikan kearifan lokal lingkungan sekitar. Hal ini bertujuan untuk memudahkan guru dalam memberikan contoh yang sesuai dengan lingkungan siswa. Alasan lainnya, yaitu agar siswa lebih mengenal kearifan lokal daerah tempat tinggalnya terlebih dahulu supaya dapat diimplementasikan pada kehidupan sehari-hari siswa secara nyata, sehingga siswa mempunyai pengalaman yang utuh sesuai dengan lingkungan sekitar (Sulistyani \& Deviana, 2019).

3) Identifikasi masalah

Masalah yang telah ditemukan peneliti dalam studi lapangan meliputi: (1) Belum tersedia bahan ajar matematika yang menyajikan aktivitas matematika yang dikaitkan dengan lingkungan sekitar, (2) Guru Matematika kelas V menjelaskan bahwa kesulitan mengajarkan konsep matematika kepada siswa selama pembelajaran daring, (3) Guru lebih banyak memberikan tugas tanpa memperhatikan ketercapaian tujuan pembelajaran dan indikator sehingga hal ini juga berpengaruh terhadap penilaian pembelajaran, dan (4) menimbulkan stigma di masyarakat bahwa pembelajaran dari rumah, Guru hanya memberi tugas kepada siswa.

4) Identifikasi Kebutuhan

Berdasarkan masalah yang ditemukan, maka peneliti mengidentifikasi kebutuhan yang harus segera diselesaikan yaitu guru dan siswa membutuhkan pengembangan LKPD matematika HOTS berorientasi kearifan lokal kota Malang untuk kelas V Sekolah Dasar. Adapun langkah awal yang dilakukan peneliti adalah menganalisis kebutuhan siswa dan guru dalam pembelajaran. Analisis kebutuhan tersebut dilakukan melalui pengamatan terhadap kesulitan apa saja yang dialami siswa dan guru dalam pembelajaran. Sehingga diperoleh tujuan umum penelitian yaitu bagaimana menghasilkan LKPD matematika HOTS berorientasi kearifan lokal kota Malang yang dapat memfasilitasi aktivitas belajar peserta didik dalam rangka meningkatkan kualitas pembelajaran matematika di sekolah dasar.

\section{b. Analisis Pembelajaran}

Tujuan analisis pembelajaran adalah mengidentifikasi kemampuan siswa dan guru sebagai pengguna LKPD matematika HOTS berorientasi kearifan lokal daerah yang akan dikembangkan. Kemampuan siswa yang diidentifikasi meliputi keterampilan, proses, prosedur dan tugas-tugas dalam kegiatan pembelajaran daring yang dilaksanakan. Sedangkan kemampuan guru yang didentifikasi meliputi perangkat pembelajaran yang digunakan, variasi kegiatan pembelajaran yang dilakukan dan tugas yang diberikan kepada siswa. Berdasarkan hasil analisis pembelajaran yang dilakukan di SD Muhammadiyah 5 Kota Malang ditemukan bahwa pembelajaran daring dilakukan melalui Grup Whatssapp (WA). Guru membuka pembelajaran melalui video yang diunggah dalam grup WA kemudian siswa mengerjakan tugas yang diberikan dan dikumpulkan kembali melalui grup WA kelas. Hal ini dapat disimpulkan bahwa pembelajaran daring yang berlangsung Guru perlu mengoreksi hasil pekerjaan siswa setiap hari untuk memberikan feedback pembelajaran. Identifikasi ini digunakan untuk merancang spesifikasi produk LKPD HOTS berorientasi Kearifan lokal kota Malang yang dikembangkan.

\section{c. Analisis Siswa dan Konteks Pembelajaran}

Analisis siswa yang dilakukan meliputi karakteristik siswa dan rata-rata umur siswa kelas V SD. Siswa kelas V SD yaitu siswa yang berusia kira-kira antara 10 - 11 tahun yang masuk dalam masa kanak-kanak akhir. Pada usia tersebut berdasarkan teori perkembangan Piaget masuk dalam tahap concrete operational thought atau pemikiran konkret-operasional (Desmita, 2010). Siswa pada tahap perkembangan ini mempunyai pemikiran yang terbatas dengan halhal yang konkret, benda-benda yang benar-benar 
nyata. Sebaliknya, benda atau peristiwa yang tidak ada hubungannya secara jelas dengan kenyataan, akan sulit dipikirkan oleh siswa.

Analisis konteks pembelajaran dilakukan untuk menentukan isi materi pembelajaran matematika yang disesuaiakan dengan kompetensi inti dan kompetensi dasar pada kelas V SD. Pada pembelajaran siswa kelas V SD perlu dikembangkan pembelajaran dengan konstruktivisme sosial. Menurut pendapat Vygotsky (dalam Thobroni \& Mustofa, 2013: 112) mengembangkan konstruktivisme sosial yang memiliki pengertian bahwa belajar bagi siswa dilakukan dalam interaksi dengan lingkungan sosial maupun fisiknya. Penemuan dalam belajar lebih mudah diperoleh dalam konteks budaya seseorang. Dengan pengalaman langsung yang diperoleh siswa, maka siswa akan membangun pemahamannya sendiri.

Selain itu, peneliti juga melakukan analisis terhadap lingkungan sekitar siswa agar LKPD yang dikembangkan sesuai dengan kehidupan nyata siswa, sehingga siswa dapat memperoleh pengalaman belajar yang lebih bermakna. LKPD matematika HOTS yang dikembangkan, dalam pengembangannya menggunakan dasar kearifan lokal Kota Malang. Adapun kearifan lokal kota malang yang diintegrasikan dalam produk LKPD matematika HOTS meliputi wisata sejarah, wisata industri, dan dinamika kekinian yang ada pada Kota Malang. Bentuk integrasi dengan lingkungan sekitar salah satu bentuknya yaitu digunakannya gambar-gambar yang hampir seluruhnya menggambarkan lingkungan dan kegiatan di Kota Malang.

Isi materi matematika di kelas V SD meliputi: (1) Penjumlahan dan pengurangan dua pecahan dengan penyebut berbeda, (2) Perkalian dan pembagian pecahan dan decimal, (3) Kecepatan, jarak, waktu, debit, (4) Skala; (5) Volume dan jaring-jaring bangun ruang, dan (7) Pengumpulan dan penyajian data. Fokus materi pada pengembangan LKPD matematika HOTS yaitu Volume dan jaring-jaring bangun ruang yang bermuatan kearifan lokal kota Malang.

\section{d. Merumuskan Tujuan Pembelajaran}

Merumuskan tujuan pembelajaran merupakan penentuan kompetensi yang akan dicapai oleh siswa setelah menggunakan LKPD
HOTS berorientasi Kearifan lokal kota Malang. Perumusan tujuan pembelajaran disesuaikan dengan hasil analisis silabus dan jaringan kompetensi dasar, analisis pelaksanaan pembelajaran, serta analisis karakteristik dan lingkungan siswa. Selanjutnya peneliti menentukan tujuan pembelajaran seara operasional dengan memperhatikan ABCD (Audience, Behavior, Condition, Degree).

\section{e. Mengembangkan Instrumen Penilaian}

Mengembangkan instrumen penilaian bertujuan untuk menyusun tes yang digunakan untuk mengevaluasi setiap pembelajaran yang telah dilaksanakan. Instrumen penilaian yang dikembangkan tidak hanya berfokus pada penilaian pengetahuan saja, melainkan juga sikap dan keterampilan. Selain itu, instrumen penilaian juga disesuaiakan dengan ranah kognitif dari taksonomi Bloom yang telah disempurnakan oleh Anderson dan Krathwohl (Arends, 2012) yang meliputi: (a) remember/ mengingat $(\mathrm{C} 1)$, (b) understand / memahami (C2), (c) apply/ menerapkan (C3), (d) analyze/menganalisa (C4), (e) evaluate/ mengevaluasi (C5, dan (f) create/ mencipta (C6). Adapun instrumen penilaian yag dikembangkan mengacu pada intrumen penilaian HOTS yang meliputi; (a) analyze/menganalisa (C4), (b) evaluate/ mengevaluasi (C5), dan (c) create/ mencipta (C6).

\section{f. Mengembangkan Strategi Pembelajaran}

Untuk mencapai tujuan pembelajaran yang telah ditetapkan maka dibutuhkan strategi pembelajaran yang tepat agar tercipta pembelajaran yang efektif. Adapun strategi pembelajaran yang dikembangkan oleh peneliti yaitu mengintegrasikan pendekatan pembelajaran saintifik (mengamati, menanya, mencoba, menalar, dan mengomunikasikan) dengan pembelajaran daring menggunakan platform Google Meet .

\section{g. Mengembangkan Bahan Pembelajaran}

LKPD matematika HOTS berorientasi Kearifan lokal kota Malang yang dikembangkan oleh peneliti memilki beberapa kriteria diantaranya yaitu : (1) kesesuaian LKPD HOTS yang dikembangkan dengan $\mathrm{KI}$ dan KD, (2) kesesuaian indikator pembelajaran dengan $\mathrm{KI}$ dan KD, (3) menyajikan kegiatan pembelajaran HOTS yang runtut untuk mencapai kompetensi yang telah ditetapkan, (4) tersedia instrumen 
penilaian yang sesuai untuk mengukur pemahaman siswa setelah menggunakan LKPD matematika HOTS berorientasi Kearifan lokal Kota Malang.

\section{h. Evaluasi Formatif}

Evaluasi formatif bertujuan untuk mendapatkan data untuk merevisi produk yang telah dikembangkan. Adapun alat ukur yang digunakan adalah angket penilaian yang diperoleh dari subjek uji coba. Subjek uji coba yang digunakan dalam evaluasi formatif adalah validator ahli, guru kelas dan siswa kelas V SD Muhammadiyah 5 Kota Malang. Langkah yang dilakukan pada evaluasi formatif meliputi; (a) melakukan uji coba prototipe (validasi ahli), (b) uji coba kelompok kecil dan (c) uji coba lapangan. Adapun penjabaran masing-masing langkah sebagai berikut;

1. Uji Coba prototipe (Validasi Ahli)

Validasi ahli dilakukan untuk menilai tingkat kevalidan produk yang telah dikembangkan. Data validasi ahli yang diperoleh peneliti yaitu validasi ahli materi. Validasi ahli materi dilakukan untuk mengevaluasi kevalidan isi atau materi pembelajaran matematika yang dipilih dalam LKPD matematika HOTS berorientasi kearifan lokal kota Malang. Ahli materi pengembangan LKPD matematika HOTS ini yaitu EY, beliau merupakan salah satu dosen S1 Pendidikan Guru Sekolah Dasar Universitas Muhammadiyah Malang bidang keahlian pembelajaran matematika. Proses validasi dilakukan peneliti dengan menyerahkan produk yang dikembangkan berupa LKPD matematika HOTS berorientasi kearifan lokal Kota Malang dan dilengkapi dengan instrumen validasi. Adapun data hasil validasi ahli materi disajikan pada Tabel 2 berikut.

Tabel 2. Data Validasi Ahli Materi

\begin{tabular}{clcc}
\hline No. & \multicolumn{1}{c}{$\begin{array}{c}\text { Aspek } \\
\text { Penilaian }\end{array}$} & \multicolumn{2}{c}{ Skor } \\
\cline { 3 - 4 } & Perolehan & Maksimal \\
\hline Kelengkapan & 19 & 20 \\
komponen & & \\
LKPD & & 12 \\
2. & $\begin{array}{l}\text { Relevansi } \\
\text { materi }\end{array}$ & 12 & 20 \\
3. & $\begin{array}{l}\text { Ketepatan } \\
\text { 4. }\end{array}$ & 18 & 20 \\
Pembelajaran & 18 & 20 \\
tematik & $\begin{array}{l}\text { Student } \\
\text { centered }\end{array}$ & 20 & 12 \\
6. & $\begin{array}{l}\text { Apresiasi } \\
\text { terhadap }\end{array}$ & 11 & \\
& & & \\
\end{tabular}

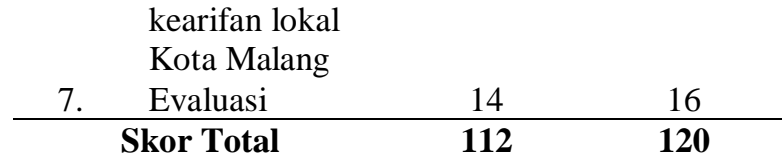

Berdasarkan tabel 2 di atas dapat diketahui bahwa angket validasi ahli materi terdiri dari 7 aspek penilaian yang kemudian dikembangkan menjadi 30 butir pertanyaan angket validasi ahli materi. Hasil validasi ahli materi terhadap produk mendapat skor perolehan yaitu 112 dari skor maksimal 120.

Validator ahli materi juga memberikan tanggapan dan masukan yang ditulis pada lembar saran tentang materi LKPD matematika HOTS pada instrumen validasi. Saran validator terhadap materi/isi LKPD matematika HOTS sebagai berikut: (1) penulisan judul pada sampul (cover) modul hendaknya ditulis menyatu (tidak terpisah-pisah); (2) kearifan lokal untuk materi tentang menganalisis ciri-ciri jaring-jaring bangun ruang kubus masih belum begitu nampak.

2. Uji coba kelompok kecil

Uji coba kelompok kecil dilakukan untuk memperoleh data kemenarikan LKPD Matematika HOTS berorientasi kearifan lokal kota Malang. Uji coba kelompok kecil dilakukan dalam bentuk simulasi pembelajaran selama \pm 90 menit. Berikut data uji coba kelompok kecil akan disajikan pada tabel 3 .

Tabel 3. Hasil Angket Uji Coba Kelompok Kecil

\begin{tabular}{clcc}
\hline \multirow{2}{*}{ No. } & Nama & \multicolumn{2}{c}{ Skor } \\
\cline { 3 - 4 } & Siswa & Perolehan & Maksimal \\
\hline 1. & SVP & 55 & 60 \\
2. & KEF & 52 & 60 \\
3. & SMP & 49 & 60 \\
4. & RDW & 51 & 60 \\
5. & KBK & 53 & 60 \\
6. & AMP & 46 & 60 \\
\hline \multicolumn{2}{r}{ Skor Total } & $\mathbf{3 0 6}$ & $\mathbf{3 6 0}$ \\
\hline Skor Rata-rata & $\mathbf{5 2}$ & $\mathbf{6 0}$ \\
\hline
\end{tabular}

Berdasarkan tabel 3 diketahui bahwa hasil penilaian angket uji coba kelompok kecil memperoleh hasil dengan perolehan skor tertinggi 55 dan perolehan skor terendah yaitu 46. Dari tabel tersebut juga diketahui hasil data respon siswa pada uji coba kelompok kecil mendapatkan skor rata-rata sebesar 52 dari skor maksimal 60. 
Pada uji coba kelompok kecil, siswa juga memberikan tanggapan dan masukan yang ditulis pada lembar saran tentang penggunaan bahasa pada LKPD matematika HOTS pada instrumen penilaian. Dari saran dan masukan uji coba kelompok kecil, data disimpulkan sebagai berikut: (1) gambar yang ada dalam LKPD sebaiknya diberikan keterangan lokasi gambar itu berada; (2) gambar yang ada di dalam LKPD terlalu sedikit; (3) terdapat beberapa kosa kata baru yang kurang dimengerti hendaknya diberikan penjelasan; (4) dalam menulis teks harus teliti lagi agar tidak ada kata-kata yang salah; dan (5) LKPD sangat menarik dan senang belajar menggunakan LKPD.

3. Uji Coba Lapangan

Uji coba lapangan dilaksanakan di kelas V SD Muhammadiyah 5 Kota Malang. Uji coba ini dilakukan untuk mengetahui aspek kepraktisan dan keefektifan LKPD matematika HOTS berorientasi kearifan lokal kota Malang. Aspek kepraktisan dapat diketahui berdasarkan tanggapan siswa dan guru. Aspek keefektifan dapat diketahui berdasarkan aktivitas siswa dan hasil belajarnya.

a) Data Angket Siswa tentang Kepraktisan Produk

Data angket siswa berisi tentang tanggapan siswa terhadap LKPD matematika HOTS berorientasi kearifan lokal kota Malang. Tanggapan yang dituliskan siswa yaitu secara umum LKPD yang sudah dikembangkan baik, mereka tertarik dan senang mengerjakan lembar kegiatan yang disajikan. Selain itu, siswa juga memberikan saran untuk perbaikan yaitu ada beberapa kalimat yang salah cetak sebaiknya diperbaiki. Adapun data hasil penilaian angket siswa akan disajikan pada tabel 4 berikut.

\begin{tabular}{clcc}
\multicolumn{2}{c}{ Tabel 4 Hasil Perhitungan Angket Respon Siswa } \\
\hline No. & \multicolumn{2}{c}{ Nama } & \multicolumn{2}{c}{ Skor } \\
\cline { 3 - 4 } & \multicolumn{1}{c}{ Siswa } & Perolehan & Maksimal \\
\hline 1. & BRO & 58 & 60 \\
2. & Hy & 52 & 60 \\
3. & INM & 52 & 60 \\
4. & IRH & 53 & 60 \\
5. & KF & 58 & 60 \\
6. & KFV & 53 & 60 \\
7. & LEM & 52 & 60 \\
8. & MM & 57 & 60 \\
9. & NYE & 57 & 60 \\
10. & NWK & 51 & 60
\end{tabular}

\begin{tabular}{clcc}
\hline \multirow{2}{*}{ No. } & Nama & \multicolumn{2}{c}{ Skor } \\
\cline { 3 - 4 } & Siswa & Perolehan & Maksimal \\
\hline 11. & NNTF & 52 & 60 \\
12. & OAAA & 50 & 60 \\
13. & PDA & 60 & 60 \\
14. & PSU & 55 & 60 \\
15. & RVN & 54 & 60 \\
16. & RTP & 60 & 60 \\
17. & RSP & 53 & 60 \\
18. & SEP & 50 & 60 \\
19. & SJ & 49 & 60 \\
20. & SS & 54 & 60 \\
21. & SAS & 56 & 60 \\
22. & YGP & 55 & 60 \\
23. & YDC & 56 & 60 \\
24. & GDD & 48 & 60 \\
25. & DMN & 52 & 60 \\
\hline & Total & $\mathbf{1 3 4 7}$ & $\mathbf{1 5 0 0}$ \\
\hline \multicolumn{2}{r}{ Rata-rata Kelas } & $\mathbf{5 4}$ & $\mathbf{6 0}$ \\
\hline
\end{tabular}

b) Data Angket Guru tentang Kepraktisan Produk

Angket respon guru diisi oleh MS, beliau adalah guru kelas V SD Muhammadiyah 5 Kota Malang. Peneliti menyerahkan produk pengembangan berupa LKPD matematika HOTS berorientasi kearifan lokal Kota Malang serta angket respon guru. Adapun data hasil penilaian angket respon guru akan disajikan pada tabel 5 berikut.

Tabel 5 Hasil Perhitungan Angket Respon Guru

\begin{tabular}{|c|c|c|c|}
\hline \multirow[t]{2}{*}{ No. } & \multirow{2}{*}{$\begin{array}{c}\text { Aspek } \\
\text { Penilaian }\end{array}$} & \multicolumn{2}{|c|}{ Skor } \\
\hline & & Perolehan & Maksimal \\
\hline 1. & $\begin{array}{l}\text { Petunjuk } \\
\text { penggunaan } \\
\text { LKPD untuk } \\
\text { guru. }\end{array}$ & 6 & 8 \\
\hline 2. & $\begin{array}{l}\text { Sajian materi } \\
\text { pembelajaran. }\end{array}$ & 14 & 16 \\
\hline 3. & $\begin{array}{l}\text { Penyajian } \\
\text { bahasa. }\end{array}$ & 6 & 8 \\
\hline 4. & $\begin{array}{l}\text { Kemampuan } \\
\text { LKPD pada } \\
\text { aktivitas belajar } \\
\text { siswa. }\end{array}$ & 29 & 32 \\
\hline 5. & $\begin{array}{l}\text { Implementasi } \\
\text { media pada } \\
\text { LKPD dalam } \\
\text { proses } \\
\text { pembelajaran. }\end{array}$ & 17 & 20 \\
\hline 6. & $\begin{array}{l}\text { Kemapuan } \\
\text { LKPD dalam } \\
\text { refleksi dan } \\
\text { evaluasi } \\
\text { pembelajaran. }\end{array}$ & 19 & 20 \\
\hline
\end{tabular}




\begin{tabular}{lcc} 
7. $\begin{array}{l}\text { Dampak pada } \\
\text { pembentukan } \\
\text { sikap. }\end{array}$ & 15 & 16 \\
\hline Skor Total & $\mathbf{1 0 6}$ & $\mathbf{1 2 0}$ \\
\hline
\end{tabular}

Guru memberikan tanggapan dan saran perbaikan terhadap penggunaan saol berbasis teknologi informasi. Adapun saran perbaikan tersebut yaitu (1) pada petunjuk guru untuk penilaian non tes, pada aspek penilaian non tes "keaktifan siswa" untuk indikatornya sebaiknya diganti dengan keaktifan siswa dalam diskusi kelas; (2) ada beberapa kata dalam teks yang masih terdapat kesalahan pengetikan, agar lebih dicermati lagi; (3) pada kunci jawaban soal evaluasi, untuk soal pertanyaan yang memungkinkan adanya beberapa alternatif jawaban diberikan keterangan untuk guru; (4) LKPD ini memiliki pengembangan materi yang cukup luas dan diintegrasikan dengan lingkungan daerah memberikan sesuatu yang baru dan menarik bagi pembelajaran siswa.

c) Aktivitas dan hasil belajar

Data aktivitas siswa diperoleh berdasarkan kegiatan pembelajaran yang telah dilakukan selama menggunakan LKPD matematika HOTS berorientasi kearifan lokal kota Malang. Adapun data aktivitas belajar siswa akan disajikan pada tabel 6 berikut.

Tabel 6 Data hasil aktivitas siswa mengerjakan LKPD HOTS

\begin{tabular}{ccccccccc}
\hline Kelas & $\begin{array}{c}\text { Rentang } \\
\text { Skor }\end{array}$ & \multicolumn{8}{c}{ Frekuensi tiap LK } \\
\cline { 3 - 8 } & & $\mathbf{1}$ & $\mathbf{2}$ & $\mathbf{4}$ & $\mathbf{5}$ & $\mathbf{6}$ & $\begin{array}{r}\text { Rata } \\
\text {-rata }\end{array}$ \\
\hline 1 & $<75$ & 3 & 2 & 0 & 4 & 4 & 2 & 2 \\
2 & $76-80$ & 4 & 2 & 1 & 1 & 0 & 2 & 1 \\
3 & $81-85$ & 2 & 3 & 2 & 1 & 1 & 1 & 4 \\
4 & $86-90$ & 5 & 7 & 3 & 3 & 2 & 8 & 3 \\
5 & $91-95$ & 3 & 4 & 4 & 6 & 3 & 3 & 6 \\
5 & $96-100$ & 8 & 7 & 15 & 10 & 15 & 9 & 9 \\
\hline & Jumlah & $\mathbf{2 5}$ & $\mathbf{2 5}$ & $\mathbf{2 5}$ & $\mathbf{2 5}$ & $\mathbf{2 5}$ & $\mathbf{2 5}$ & $\mathbf{2 5}$ \\
\hline
\end{tabular}

Berdasarkan data yang ditunjukkan tabel 6 dapat diketahui bahwa untuk tiap-tiap lembar kegiatan terdapat beberapa siswa yang tidak mencapai KKM yang ditetapkan yaitu mencapai skor $\geq 75$ dari 100. Banyaknya siswa yang tidak tuntas pada tiap-tiap lembar kegiatan dipaparkan sebagai berikut: (1) pada LK 1 terdapat 3 siswa yang tidak tuntas; (2) pada LK 2 terdapat 2 siswa yang tidak tuntas; (3) pada LK 3 semua siswa tuntas; (4) pada LK 4 terdapat 4 siswa yang tidak tuntas; (5) pada LK 5 terdapat 4 siswa yang tidak tuntas; dan (6) pada LK 6 terdapat 2 siswa yang tidak tuntas. Secara keseluruhan berdarkan ratarata nilai masing-masing siswa terdapat 2 siswa yang tidak tuntas.

\section{REVISI PRODUK.}

Revisi produk dapat dilakukan pada setiap langkah atau tahapan penelitian dan pengembangan yang telah ditentukan oleh peneliti. Tujuan dari revisi produk yaitu untuk memperbaiki kualitas LKPD matematika HOTS berorientasi kearifan lokal kota Malang yang dikembangkan berdasarkan saran dan perbaikan yang diperoleh dari hasil uji coba. Sehingga revisi diharapkan dapat meningkatkan tingkat kevalidan, kemenarikan, kepraktisan dan keefektifan LKPD matematika HOTS berorientasi kearifan lokal kota Malang yang digunakan sebagai bahan ajar bagi guru dan siswa.

\section{KESIMPULAN}

Berdasarkan hasil penelitian yang dilakukan di SD Muhammadiyah 5 Kota Malang ditemukan bahwa pengembangan LKPD matematika HOTS berorientasi kearifan lokal kota Malang dapat digunakan sebagai bahan ajar pada pembelajaran matematika di Sekolah Dasar. Selain itu LKPD HOTS dapat mengukur sejauh mana kompetensi yang dicapai peserta didik dalam rangka meningkatkan kualitas pembelajaran matematika di sekolah dasar. Selain itu, Guru dapat melakukan analisis tujuan pembelajaran yang belum dikuasai oleh siswa.

\section{SARAN}

Rekomendasi untuk penelitian selanjutnya yaitu pengembangan LKPD matematika HOTS berorientasi kearifan lokal kota Malang pada pembelajaran Matematika pada jenjang kelas lainnya misalnya kelas $1,2,3$ 4 dan 6.

\section{UCAPAN TERIMA KASIH}

Penelitian ini terlaksana atas dukungan Direktorat Penelitian dan Pengabdian Masyarakat (DPPM) Universitas Muhammadiyah Malang serta fasilitas dari sekolah mitra SD Muhammadiyah 5 Kota 
Malang. Terimakasih kami ucapkan atas kerjasama dan kolaborasi yang baik selama Program Penelitian Pengembangan IPTEKS ini.

\section{DAFTAR PUSTAKA}

Dick, Walter., Carey, Lou., Carey, James O. 2009. The Systematical Design of Instruction. USA: Pearson.

Fitria, A., Wijaya, M., \& Danial, M. (2020). Pengembangan Lembar Kerja Peserta Didik (LKPD) Berbasis High Order Thinking Skill (HOTS). Chemistry Education Review (CER), 3(2). https://doi.org/10.26858/cer.v3i2.13767

Florea, N. M., \& Hurjui, E. (2015). Critical Thinking in Elementary School Children. Procedia - Social and Behavioral Sciences. https://doi.org/10.1016/j.sbspro.2015.0 2.161

Kertih, I. W. (2020). Character Education of Balinese Local Wisdom-Based Through the Integration Social Studies Subject. https://doi.org/10.2991/assehr.k.200803 .031

Muzayyanah, A., Wijayanti, A., \& Ardiyanto, A. (2020). Pengembangan Lembar Kerja Peserta Didik (LKPD) Tematik Berbasis HOTS (Higher Order Thinking Skill) Kelas IV Sekolah Dasar. Jurnal Pijar Mipa, 15(5), 452. https://doi.org/10.29303/jpm.v15i5.196 1

Nasution, M. (2016). Character education based on local wisdom. Proceding International Seminar Culture Change and Sustainable Development in Multidisciplinary Approach: Education, Environment, Art, Politic, Economic, Law, and Tourism, 106-110. Retrieved from https://ojs.unud.ac.id/index.php/iccs/art icle/view/52997/31338

Noprinda, C. T., \& Soleh, S. M. (2019). Pengembangan Lembar Kerja Peserta Didik (LKPD) Berbasis Higher Order Thinking Skill (HOTS). Indonesian Journal of Science and Mathematics Education, 2(2). https://doi.org/10.24042/ijsme.v2i2.434
2

Retnawati, H., Djidu, H., Kartianom, Apino, E., \& Anazifa, R. D. (2018). Teachers' knowledge about higher-order thinking skills and its learning strategy. Problems of Education in the 21st Century, 76(2), 215-230.

Septian, R., Irianto, S., \& Andriani, A. (2019). PENGEMBANGAN LEMBAR KERJA PESERTA DIDIK (LKPD) MATEMATIKA BERBASIS MODEL REALISTIC MATHEMATICS EDUCATION. Jurnal Educatio FKIP UNMA, $5(1)$. https://doi.org/10.31949/educatio.v5i1. 56

Sulistyani, N., \& Deviana, T. (2019). Analisis Bahan Ajar Matematika Kelas V Sd Di Kota Malang. Jurnal Pemikiran Dan Pengembangan Sekolah Dasar (JP2SD), 7(2).

Umbaryati. (2018). Pentingnya LKPD pada Pendekatan Scientific Pembelajaran Matematika. Universitas Lampung.

Widodo, S. (2017). Pengembangan Lembar Kegiatan Peserta Didik (LKPD) berbasis Pendekatan Saintifik untuk Meningkatkan Keterampilan Penyelesaian Masalah Lingkungan Sekitar Peserta Didik di Sekolah Dasar. JPIS Jurnal Pendidikan Ilmu Sosial, 26(2). 